\title{
Provincial Competitiveness Index of Thai Nguyen Province, Vietnam
}

\author{
Ma Thi Hang, Phung Tran My Hanh, and Ma Thi Huyen Nga
}

\section{ABSTRACT}

Thai Nguyen province; is one of the political, economic, and educational centers of the Northern mountainous midland in developing countries like Vietnam. This paper examines the influencing of Thai Nguyen PCI index on explores and explains why provinces outperform others in private economic development, job creation and economic growth, thereby providing useful information. The results show Thai Nguyen PCI index is increasingly ranked high in the country and ranked first in the northern mountainous provinces in Vietnam.

Keywords: PCI, Thai Nguyen province, Rank.

\author{
Submitted : June 14, 2021 \\ Published : July 15, 2021 \\ ISSN: 2507-1076 \\ DOI: $10.24018 / \mathrm{ejbmr} .2021 .6 .4 .934$ \\ MaThi Hang \\ Thai Nguyen College of Economics and \\ Techniques, Thai Nguyen, Vietnam. \\ Phung Tran My Hanh* \\ Thai Nguyen University of Economics \\ and Business Administration, Thai \\ Nguyen, Vietnam. \\ (e-mail: \\ phungtranmyhanh.tueba@ ${ }^{@}$ tueba.edu.vn) \\ Ma Thi Huyen Nga \\ Thai Nguyen University of Economics \\ and Business Administration, Thai \\ Nguyen, Vietnam. \\ *Corresponding Author
}

\section{INTRODUCTION}

Provincial Competitiveness Index is an index that measures and evaluates the actual quality of economic governance of provinces and cities in Vietnam, thereby promoting the development of the private economic sector of 63 provinces and cities in Vietnam. The PCI index can be considered as the "voice collection" of the private business community on the business environment in provinces and cities in Vietnam[4].

The PCI index is not intended for scientific research alone or to praise or criticize provinces with high or low PCI scores. Instead, the PCI index explores and explains why some provinces and cities outperform others in private economic development, job creation and economic growth, thereby providing useful information. It is useful for leaders of provinces and cities to identify areas and ways to implement economic governance reforms most effectively. Thai Nguyen province is one of the political, economic, and educational centres of the Northern mountainous midland in Vietnam. Thai Nguyen province with favourable conditions on geographic location, socio-economic characteristics; has created favourable conditions for the enterprise's development. In addition, with the policies about investment and enterprise development of Thai Nguyen's provincial leaders, many industrial zones and enterprises have established and attracted thousands of labours from other provinces to work; especially with the number of Industrial enterprises and employees who worked in this area increasing annually per year [2].
On December 31, 2020, the Executive Committee of the Party Committee of Thai Nguyen province issued Resolution No. 01-NQ/TU on the province's college program for the period 2021-2025, with a vision to 2030. On December 31 every year is taken as the date of the Communist Party of Thai Nguyen province. Resolution No. 01- NQ/TU sets out the goals to strive for: By 2025, Thai Nguyen is in the group of 15 leading cities and provinces nationwide in terms of colleges. The specific and basic goal by 2030 is that of a digital government with over $90 \%$ of people and businesses satisfied with online public services; $100 \%$ of work records at the provincial level, $90 \%$ at the district level and $70 \%$ at the commune level are processed in the network environment. Forming a data platform for economic sectors based on data of State agencies, Internet of Things infrastructure; 30\% reduction in administrative procedures, opening data for organizations and businesses. Over $70 \%$ of bar operations, checks are done in digital environment. Promote the development of the digital economy, improve the competitiveness of the economy, in which the digital economy accounts for $30 \%$ of GRDP; strive to have 3000 number of enterprises. Formation and rapid development of a Thai Nguyen is a digital society with broadband fiber optic cable $5 \mathrm{G}$ mobile service, $80 \%$ of people have electronic payment accounts [1].

In the period 2010-2019, Thai Nguyen province has unstable PCI competitiveness index ranking. According to Table 1, in 2010, Thai Nguyen was ranked in the group of provinces with PCI index in the group of "Good" with a score of 56.64, ranked $42 / 63$ provinces and cities nationwide and 
ranked 5/14 provinces in the region. northern mountains. However, in 2011, the province's PCI was ranked 57 out of 63 provinces and cities nationwide (down 15 places compared to 2010) and ranked 12th out of 14 northern mountainous provinces. The sharp decrease of the PCI index is a very meaningful lesson and for Thai Nguyen province to be aware of the province's competitiveness through external assessments, from enterprises' assessment of the environment investment and business school of the province. From being aware of the limitations and timely overcoming, in 2012, the PCI ranking of Thai Nguyen province increased dramatically to 17 th position out of 63 provinces and cities across the country (up 40 places compared to 2012); ranked 2nd out of 14 mountainous provinces in the North and in the group of "Good". With the efforts of all sectors and levels, the companionship of the business community, the investment and business environment of Thai Nguyen province has been continuously improved. The province's competitiveness index for 3 consecutive years $(2014,2015$, and 2016) is in the top 10 provinces with the highest PCI in the country, classified in the "Good" operating group.

This paper aims to clarify the background of Thai Nguyen PCI index for Industry enterprise. The present analysis provides practically useful implications. Based on the results, the article summarizes recent discussion on Thai Nguyen PCI index.

\section{MethodOlOGY}

Secondary data of the Vietnam Chamber of Commerce and Industry (VCCI), regarding PCI index ranking in Thai Nguyen and some Northern provinces released on annual year ranking was used in order to analyze for this research.

In this research, descriptive statistics utilize numerical and graphical methods to illustrate the PCI index ranking of Thai Nguyen province, Vietnam, to summarize the information it reveals and to present that information in a meaningful way.

Inferential statistics uses the data to make estimates, decisions, predictions, or other generalizations about the ranking of Thai Nguyen province from which the data was obtained.

\section{RESULTS AND DISCUSSION}

By 2017 and 2018, Thai Nguyen province's ranking dropped to $15 / 63$ and $18 / 63$ across the country, classified as "Good". However, Thai Nguyen still ranks second in the PCI ranking of northern mountainous provinces, after Lao Cai. At the Conference on evaluating performance in 2018, implementing tasks in 2019 and implementing Resolution No. 09-NQ/TU of the Provincial Party Committee on improving the business environment, enhancing competitiveness In the
PCI provincial competition, the delegates raised the remaining issues such as: The awareness of the PCI index of some localities, units and officials is not high; The investigation and survey of enterprises is still limited. In addition, the issues of mechanisms, policies, consulting activities, business support; training a qualified workforce as well as the professional capacity of a part of civil servants when performing official duties has not met the set requirements.

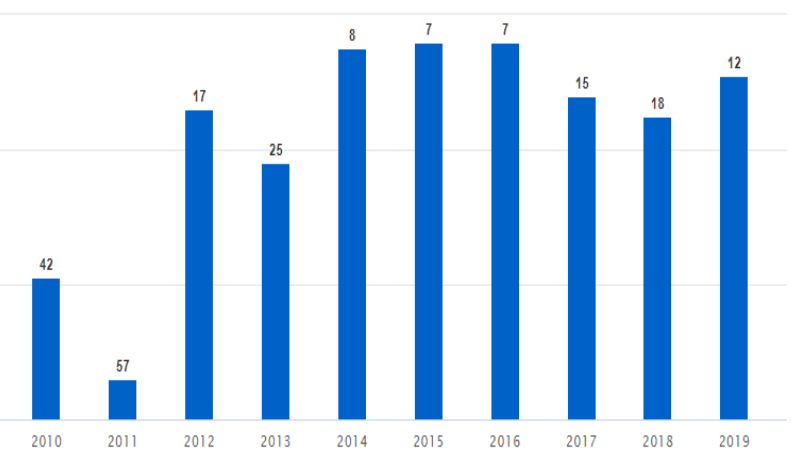

Fig 1. PCI index of Thai Nguyen province in Vietnam in the period 20102019

On that basis, the People's Committee of Thai Nguyen Province issued policies to implement the implementation. implementing Resolution No. 09-NQ/TU of the Provincial Party Committee on improving the business environment, enhancing the competitiveness of the CPI province; so by 2019 Thai Nguyen's PCI ranking ranked 12th out of 63 provinces and cities across the country; leading the group of northern mountainous provinces, also the five provinces with the highest score in the period 2010-2019 and in the group of provinces with good governance quality... with a total score of 67.71 points, an increase of 6 places and 3.47 points higher than 2018.

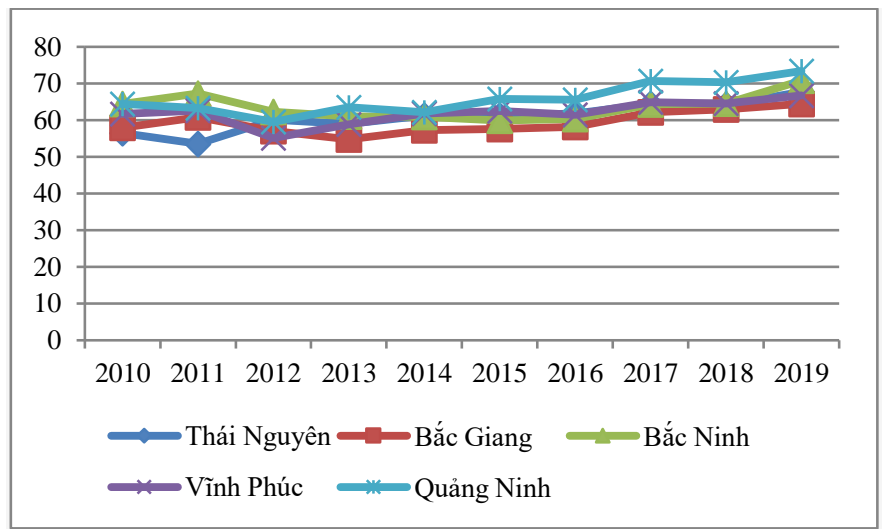

Fig. 2. Comparing PCI index of Thai Nguyen province with some northern provinces in Vietnam.

TABLE I: PCI INDEX RANKING OF THAI NGUYEN PROVINCE, VIETNAM

\begin{tabular}{|c|c|c|c|c|c|c|c|c|c|c|}
\hline Index & 2010 & 2011 & 2012 & 2013 & 2014 & 2015 & 2016 & 2017 & 2018 & 2019 \\
\hline PCI score & 56,54 & 53,57 & 60,07 & 58,96 & 61,25 & 61,21 & 61,82 & 64,45 & 64,24 & 67,71 \\
\hline National ranking & 42 & 57 & 17 & 25 & 8 & 7 & 7 & 15 & 18 & 12 \\
\hline $\begin{array}{c}\text { Northern } \\
\text { Mountain Rank }\end{array}$ & 5 & 12 & 2 & 2 & 2 & 2 & 2 & 2 & 2 & 1 \\
\hline Executive team & $\begin{array}{c}\text { Graded } \\
\text { fairly }\end{array}$ & $\begin{array}{c}\text { Graded } \\
\text { fairly }\end{array}$ & Good & $\begin{array}{c}\text { Graded } \\
\text { fairly }\end{array}$ & Good & Good & Good & $\begin{array}{c}\text { Graded } \\
\text { fairly }\end{array}$ & $\begin{array}{c}\text { Graded } \\
\text { fairly }\end{array}$ & Good \\
\hline
\end{tabular}


In the years from 2012 to 2019, Thai Nguyen's PCI ranking has always kept the $2^{\text {nd }}$ position out of 14 provinces in the Northern mountainous region, especially in 2019 it has risen to the top. When comparing this index with the northern provinces that have quite similar advantages in terms of geographical location, climate ... (such as Quang Ninh, Bac Ninh, Bac Giang and Vinh Phuc) it shows that the PCI index of Thai Nguyen province in 2010 was at the lowest level, but by 2019 Thai Nguyen's PCI index ranked higher than Bac Giang and Vinh Phuc; behind Bac Ninh and Quang Ninh.

The past 2020 has been a special year when the business community, the government system had to strain to cope with the COVID-19 pandemic, a serious global health disaster, negatively and directly affecting the health of the community business investment activities of enterprises, from small enterprises to large corporations, from tourism and service enterprises to manufacturing enterprises, from high mountains to big cities. Therefore, the impact of COVID-19 on Vietnamese businesses and shows a difficult picture of the business community, in which the positive points are businesses appreciate the timely response and supportive policies from the Government and local authorities.

The PCI survey shows that the quality of provincial economic governance in Vietnam, especially Thai Nguyen province tends to improve over time. Positive movements were noted including unofficial costs, continuing downward momentum; security and order are maintained; provincial government is more dynamic and pioneering.

Administrative reform has significantly improved, and the business environment is more and more equal. However, the survey results also show that the provincial government needs to drastically improve the transparency of the business environment, improve the enforcement quality of the local government system, continue to reform procedures administrative costs, and reduce the burden of inspection and examination of enterprises, continuing efforts to cut informal costs for enterprises.

\section{REFERENCES}

[1] Improving PCI and digital transformation: Term 3- Expecting Thai Nguyen to be in the top 10. (Nâng cao Chỉ số PCI và công cuộc chuyển đổi số: Kỳ 3 - Kỳ vọng Thái Nguyên đứng trong tốp 10). $\mathrm{http} / / /$ daithainguyen.vn/chi-tiet-tin-tuc/nang-cao-chi-so-pci-va-congcuoc- chuyen-doi-so-ky-3-ky-vong-thai-nguyen-dung-trong-top-1025783.html.

[2] Thai Nguyen statistics office, 2020. Thai Nguyen Statistical Yearbook 2019. Thai Nguyen statistics publishing.

[3] Vietnam Chamber of Commerce and Industry, 2010-2019. Vietnam Provincial Competitiveness Index 2010 - 2019. VCCI.

[4] Vietnam Chamber of Commerce and Industry, 2016. PCI Handbook Guide to using the results of the provincial competitiveness index survey to improve the business environment. (Sổ tay PCI Hướng dẫn sử dụng kết quả điều tra chỉ số năng lực cạnh tranh cấp tỉnh nhằm cải thiện môi trường kinh doanh). Ha Noi, Vietnam.

[5] Thai Nguyen City Cultural and Communication Center, 2021. 